\title{
Invasive Species of Florida's Coastal Waters: The Asian Green Mussel (Perna viridis) ${ }^{1}$
}

Maia McGuire, John Stevely ${ }^{2}$

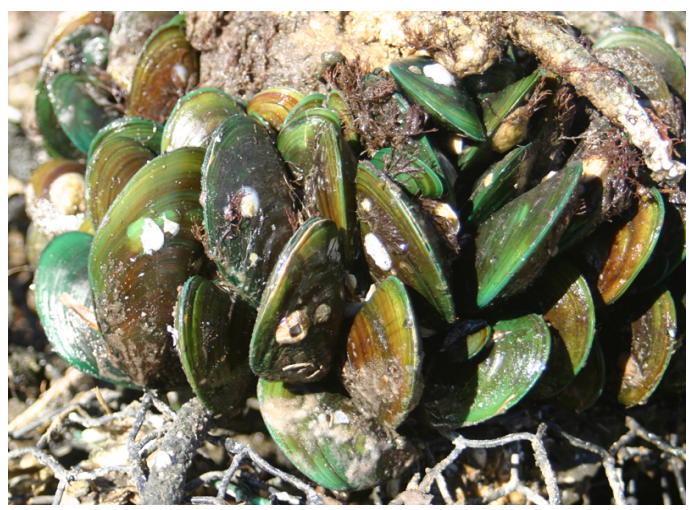

Figure 1. Green mussels growing on a crab trap retrieved from Tampa Bay, 2009. Credits: Florida Sea Grant Credits:

\section{Introduction}

Invasive species are those plants and animals that are not native to an area and which have a negative impact on native species, the environment or human health. Invasive species can also have negative economic impacts due to their interactions with economically important species and local businesses. Since 1999, a non-native marine animal, the Asian green mussel, Perna viridis (Fig. 1 and Fig. 2), has been found in numerous locations in Florida, Georgia and South Carolina (Fig. 3). Green mussels are likely to spread all along Florida's coasts where they have the potential to displace local native species such as oysters and other benthic (bottom-dwelling) invertebrates. Furthermore, green mussels are foulers of sea going ships, stormwater drains and the intakes of power plants and other industries.

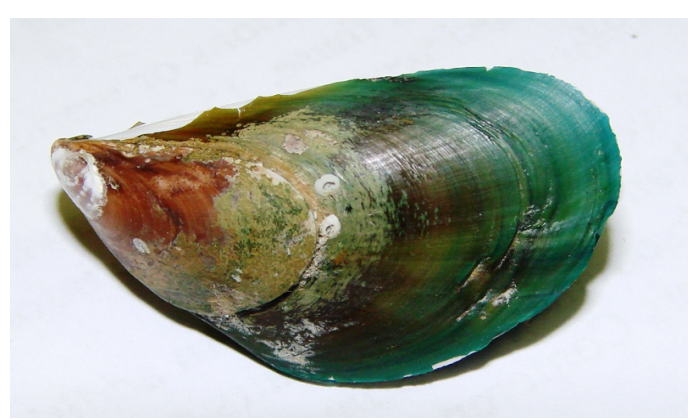

Figure 2. Adult green mussel shell. Credits: Maia McGuire, Florida Sea Grant Extension Credits:

\section{Distribution}

The native range of the green mussel is along the Indian coast and throughout the Indo-Pacific and Asian Pacific. It has been introduced to Australia, Japan, parts of the Caribbean, South America and the southeastern United States.

1. This document is SGEF-175 published by the Florida Sea Grant College Program with support from the National Oceanic and Atmospheric Administration, U.S. Department of Commerce. Published August 2009. For more information contact Florida Sea Grant, PO Box 110400, Gainesville, FL 32611-0400, 352-392-5870.

2. Maia McGuire, marine Extension agent, St. Johns and Flagler counties Cooperative Extension, Flagler County Extension Office, 150 Sawgrass Road, Bunnell, FL 32110. Inquiries may also be directed to: mpmcg@ufl.edu. John Stevely, marine Extension agent, Manatee, Sarasota and Hillsborough counties Cooperative Extension Service, 1303 17th St. West, Palmetto, FL 34421-5998. Inquiries may also be directed to: jsmarine@ufl.edu.

The Institute of Food and Agricultural Sciences (IFAS) is an Equal Opportunity Institution authorized to provide research, educational information and other services only to individuals and institutions that function with non-discrimination with respect to race, creed, color, religion, age, disability, sex, sexual orientation, marital status, national origin, political opinions or affiliations. U.S. Department of Agriculture, Cooperative Extension Service, University of Florida, IFAS, Florida A. \& M. University Cooperative Extension Program, and Boards of County Commissioners Cooperating. Millie Ferrer, Interim Dean 


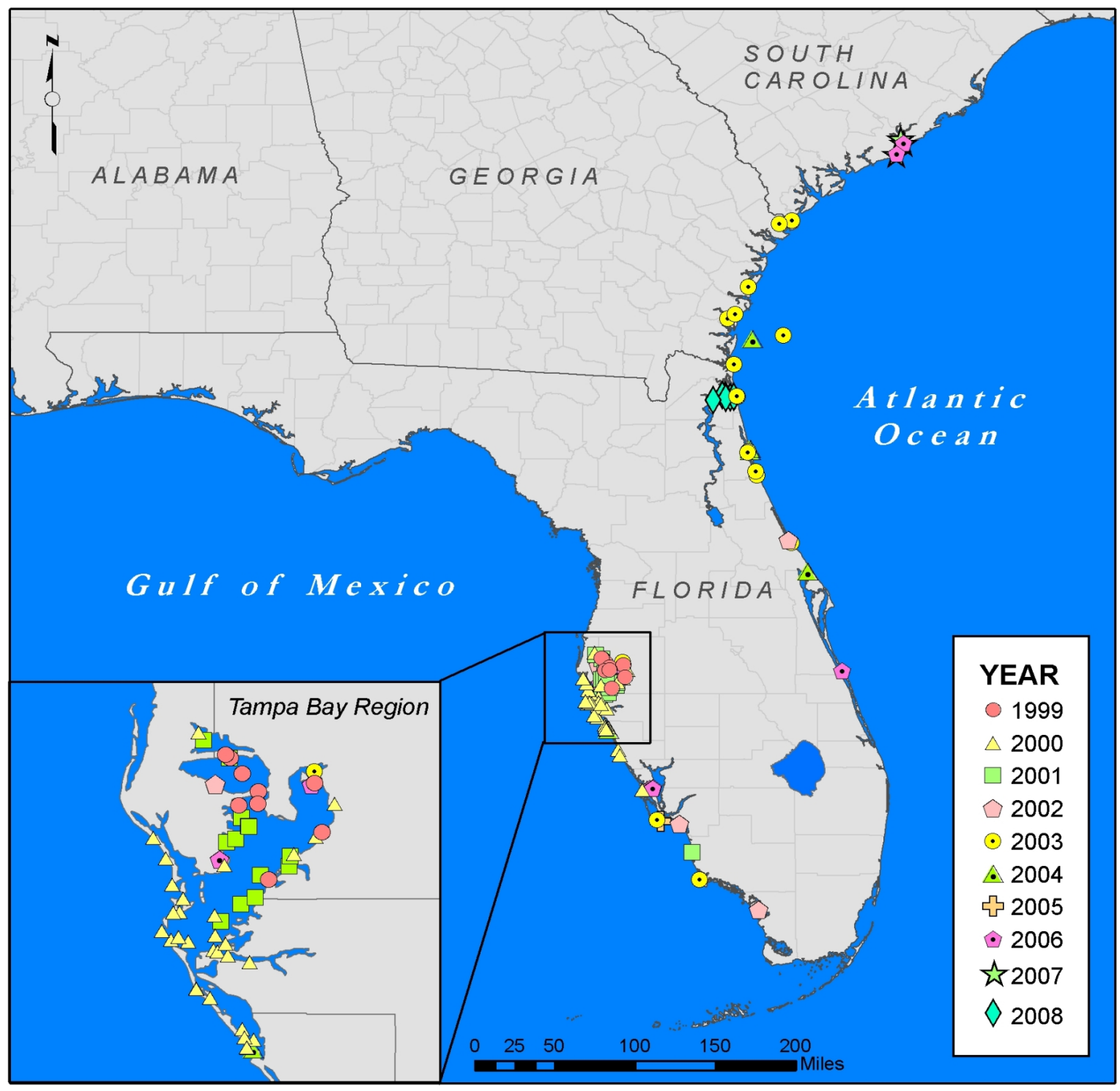

Figure 3. Reported green mussel sightings as of September, 2008. Credits: Amy Benson, USGS, Gainesville, FL Credits:

Green mussels were first observed in the Caribbean in 1990. Within 10 years, green mussels had been found along the coasts of Venezuela and Jamaica and in Tampa Bay, Florida. Since their discovery in Tampa Bay in 1999, other populations have been found in coastal regions of southwestern Florida and along the Atlantic coast of Florida from Brevard County northward. A few recruits have been found in Florida in the northern Gulf of Mexico, but no significant populations have yet been reported in that location. Green mussels were first reported in coastal Georgia in 2003; by 2006 they had spread as far north as Charleston, South Carolina. Many of the established populations of $P$. viridis are in major ports. This suggests that the introductions may have been through ballast water or from mussels attached to the hulls of boats or ships. The introduced population at Tampa Bay has expanded considerably since 1999 , most likely through local reproduction and settlement.

\section{Biology}

The green mussel is a large mussel, $80-100 \mathrm{~mm}$ (3-4 inches) in length, occasionally reaching $165 \mathrm{~mm}$ (6.5 inches). The shell has a smooth, exterior surface which is covered by a thin, organic layer called the periostracum. The periostracum is generally intact in young mussels but may have patches peeled off in older ones. The color of the periostracum is bright 
green in juveniles, fading to brown with green edges as the mussel matures. The inner shell surface is smooth and iridescent with a bluish green hue. Native Florida mussels include the scorched mussel,

Brachidontes exustus, and ribbed mussel, Geukensia demissa, both of which have ribbed shells, and the horse mussels, Modiolus spp. None of the native mussels has a green color on the lip of the shell (Fig. $4)$.

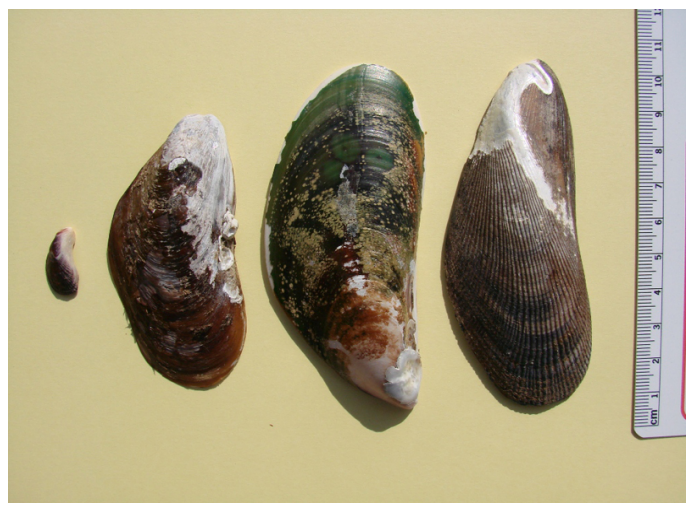

Figure 4. Left to right: scorched mussel, horse mussel, green mussel, ribbed mussel. Credits: Maia McGuire Credits:

Green mussels are filter-feeding bivalves. They attach to surfaces using byssal threads. These strong threads allow the mussels to adhere to hard surfaces, and also allow the mussels to re-attach themselves if they become dislodged. Individual animals are either male or female. Reproduction is by spawning followed by external fertilization. In Hong Kong, these mussels have two peaks in reproduction; one in the spring and one in the fall, although there are some mussels that contain gametes regardless of the time of year. Green mussels in Florida appear to have a similar reproductive pattern. Larvae are planktonic and remain swimming in the water column for 2-3 weeks. At the end of this period, the larvae settle out of the water column, metamorphose into juvenile mussels, and attach themselves to a surface by producing byssal threads. In their native environment of Southeast Asia, green mussels become reproductive at an age of only 2-3 months (20-30 mm shell length, Fig. 5). Green mussels may live as long as three years.

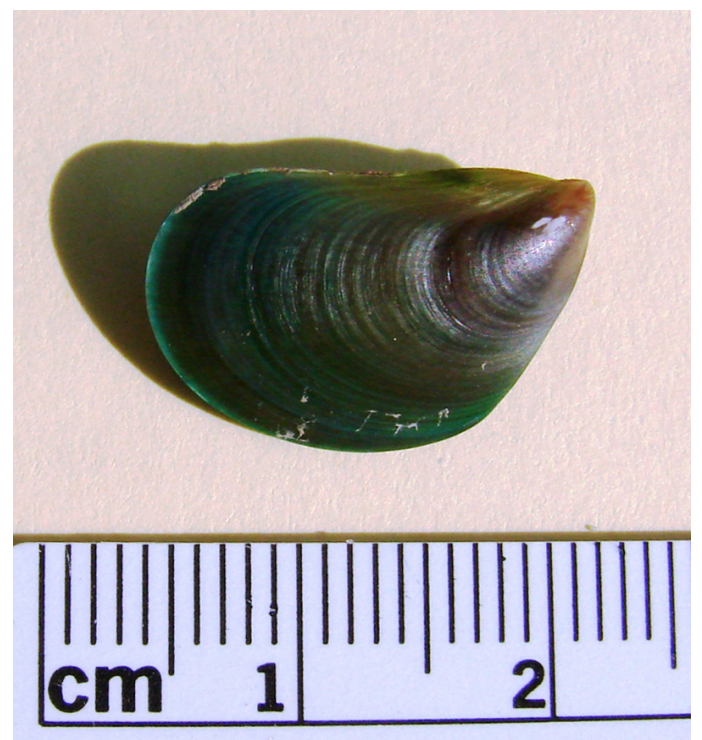

Figure 5. Two-month-old green mussel. Credits: Maia McGuire Credits:

\section{Habitat}

Green mussels are generally found growing on hard surfaces such as rocks, pilings and floating docks, however they can also be found growing on sandy or muddy bottoms. They seem to prefer to settle in areas where there is high water flow, at a depth of about $30 \mathrm{~cm}$ ( 1 foot) below the low tide mark. They often settle in cryptic areas (e.g., in crevices between boulders or on the lower side of floating objects).

Green mussels can tolerate a fairly wide range of salinities (15-45 ppt) and temperatures $\left(10^{\circ} \mathrm{C}-\right.$ $\left.42^{\circ} \mathrm{C}\right)$.

\section{Impacts}

Green mussels will foul ships, marinas, buoys and power plant intakes (Fig 6). Young green mussels settled on filters in intake pipes at an electric power plant in Tampa Bay in 1999, clogging the filters and hampering proper operations of the plant. They caused similar problems for a Tampa Bay desalination plant in 2003. Green mussels may clog crab traps and clam culture bags, making the commercial harvest of these native species more difficult. Green mussels compete with other benthic marine species for space. In Tampa Bay, green mussels have displaced some oyster reefs. For recreational boaters who keep their vessels in wet 
slips, the rapid growth of green mussels in parts of Florida requires an increase in the frequency of hull cleanings. These observations suggest that the biological and economic impact of the green mussel introduction to Florida may be considerable.

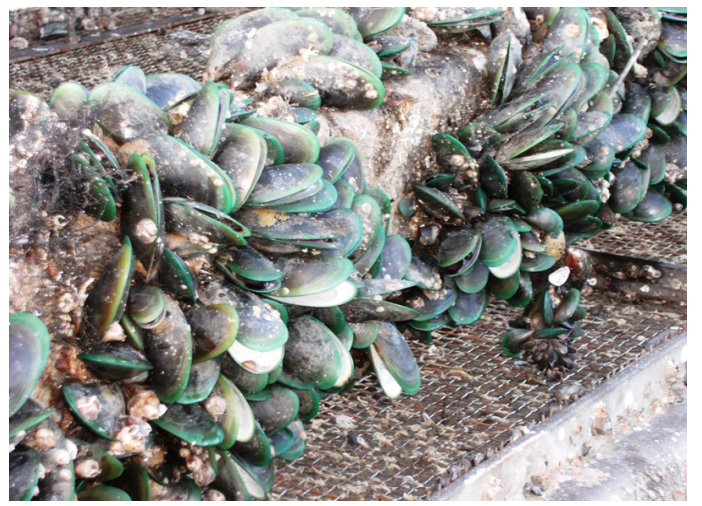

Figure 6. Filter from a power plant fouled with green mussels. Credits: Tammy Hatfield, Pelotes Island Nature Preserve, Jacksonville Credits:

Green mussels are eaten by native Florida species including blue crabs and sheepshead: however the levels of predation are not high enough to substantially reduce or eliminate populations of the mussels.

\section{What Can You Do?}

Recreational and commercial boaters should be aware that green mussels may grow on the hulls of boats that are kept in the water. Before making long-distance trips on your boat, you should have the hull visually inspected, and scraped if necessary, to remove green mussels or other non-native fouling organisms. Ideally, the boat should be hauled and cleaned at a boatyard facility that can retain the scrapings on land. To prevent transporting larvae that may be present in boat bilge water, boaters with trailered boats should drain their bilges and livewells on land when removing their boats from the water.

If you spot live green mussels, especially in regions where they have not previously been sighted (see map above, or listings at http://nas.er.usgs.gov), please report them to the U.S. Geological Survey Nonindigenous Aquatic Species Program, or by calling 877-STOP-ANS (877-786-7267).

Green mussels are similar to the New Zealand green-lipped mussel, Perna canaliculus, which is sold in seafood markets. It is illegal to harvest green mussels from Florida waters that are closed to shellfish harvest (see http://www.floridaaquaculture.com/seas/ seas_areainfo.htm for maps). In waters that are open for shellfish harvest, green mussels may only be legally harvested recreationally with a fishing license or by people who have a Commercial Products License from the state. As an invasive species, little is known about product safety of green mussels in Florida, however these mussels are known to accumulate toxins and illness-causing plankton in other parts of the world.

Florida anglers report that they have some success using green mussel meat to fish for saltwater and estuarine sportfish, including sheepshead. Because the mussel tissue is soft, it may be better used as chum rather than as bait on a hook.

For more information:

USGS Nonindigenous Aquatic Species, http://nas.er.usgs.gov

UF/IFAS Green Mussel Website, http://fishweb.ifas.ufl.edu/greenmussel/

Prevent Hull Hitchhikers, http://hullhitchers.com/ 